\title{
19: 10311307-10305452
}

National Cancer Institute

\section{Source}

National Cancer Institute. 19: 10311307-10305452. NCI Thesaurus. Code C42504.

Physical location of ICAM3_Gene 